\title{
Growth Capacity of Thermotolerant Campylobacters in Culture Media Supplemented with Pig and Cow Blood
}

\author{
Álvaro Tresierra-Ayala ${ }^{1,2}$, Manuel Navas $^{1}$, Josué Flores $^{1}$, Ramsés Perea ${ }^{1}$, Juan \\ Huanaquiri $^{1}$, María Bendayán ${ }^{1}$ and Heriberto Fernández ${ }^{3^{*}}$ \\ ${ }^{1}$ Department of Microbiology; Universidad Nacional de la Amazonia Peruana; Pevas 5ta. Cuadra; Iquitos - Perú. \\ ${ }^{2}$ Research Institute; Universidad Particular de Iquitos; Av. Quiñones Km, 2,5; Iquitos - Perú. ${ }^{3}$ Institute of Clinical \\ Microbiology; Universidad Austral de Chile; P. O. Box 567; Valdivia - Chile
}

\begin{abstract}
In this work 60 thermotolerant Campylobacter strains (37 C. jejuni and 23 C. coli) isolated from the cows, pigs, chickens and ducks (15 strains of each type of animal) were used to establish their growth capacity on media containing cow or swine blood as potential substitutes of sheep or horse blood. The growth capacity was assessed by viable counts on cow and swine blood media, using the modified Miles and Misra method. Campylobacter strains showed better growth in the media supplemented with pig or sheep blood than with cow blood. Thus, the use of pig blood could be a supplement for Campylobacter culture medium, when there was no availability of sheep or horse blood.
\end{abstract}

Key words: Campylobacter, culture media, cow blood, swine blood

\section{INTRODUCTION}

The classical thermotolerant campylobacters (Campylobacter jejuni and C. coli) are zoonotic bacteria frequently associated with human diarrhoea in both developing and industrialized countries. Many animal species harbor these agents in their intestinal tract, being dogs, cats, cows, pigs and poultry their most important household reservoirs (Fernández, 1992; TresierraAyala et al., 1995; Fernández and Pisón, 1996; Engberg, 2006; Fernández et al., 2008; Debruyne et al., 2008). Campylobacter species are strictly microaerophilic organisms that grow optimally in an atmosphere containing 5\% oxygen. Such an environment may be obtained by (a) providing a specified microaerobic gas mixture, (b) using commercial atmosphere-generating systems, or (c) culturing the organisms in a normal atmosphere in a semisolid medium that naturally provides an oxygen gradient (Stern and Kazmi, 1989; Engberg, 2006).

George et al. (1978) reported that aerotolerance of many Campylobacter strains increases when the culture media were supplemented with $0.025 \%$ each of ferrous sulfate, sodium metabisulfite, and sodium pyruvate (FBP). They suggested that incorporating the FBP supplement into media enhanced the growth of the organisms and, consequently, its recovery from samples could be improved. On the other hand, Hoffman et al. (1979) suggested that FBP might act as an oxygen and oxygen products (peroxides and superoxides) scavenger that otherwise would produce a toxic effect on these organisms. Stern and Kazmi (1984) reported that supplements of ferrous sulfate,

\footnotetext{
* Author for correspondence: hfernand@uach.cl
} 
sodium pyruvate, charcoal and blood, acting as quenching or detoxifying agents, prevented the accumulation of toxic oxygen derivatives allowing the growth of the organisms. Most of the Campylobacter culture media described in the literature are also supplemented with sheep or horse blood.

A variety of animal bloods and banked human blood are used for preparing some microbiological culture media, especially for enrichment and studying some characteristics such as hemolytic properties. In many countries, defibrinated sheep blood is accepted as the most efficient blood supplement for routine work, being horse blood recommended as the second choice (Vera and Power, 1980).

In Iquitos city (in the Peruvian jungle region, Southern latitude $3^{\circ} \quad 45^{\prime}$ ), thermotolerant campylobacters have been considered an important cause of childhood diarrhea being isolated from $23 \%$ of the cases (Grados et al., 1988). However, the routine diagnosis of Campylobacter is not implemented due to the difficulties of the clinical microbiology laboratories in obtaining sheep and horse blood easily, associated to local animal husbandry practices. The aim of this work was to study the growth capacity of these bacteria using cow and pig blood instead sheep or horse blood.

\section{MATERIAL AND METHODS}

Sixty thermotolerant Campylobacter strains (37 C. jejuni and 23 C. coli) were used in this study. They were isolated from the cloacal or rectal samples obtained from the healthy domestic animals (chickens, ducks, cows and pigs) from different peri-urban zones in Iquitos city. Once obtained, all the samples were immediatly placed into the transport and enrichment medium proposed by Fernández (1992), consisting of (w/v\%): Brucella broth (Difco) $2.8 \mathrm{~g}$; agar (Difco) $0.15 \mathrm{~g}$; ferrous sulphate (Merck) $0.05 \mathrm{~g}$, sodium metabisulfite (Merck) $0.05 \mathrm{~g}$; sodium pyruvate (Merck) $0.05 \mathrm{~g}$, trimethoprim (Sigma) $1 \mathrm{mg}$; rifampicin (Sigma) $1.5 \mathrm{mg}$; colistin (Sigma) $1000 \mathrm{IU}$; amphotericine (Squibb) $1 \mathrm{mg}$ and defibrinated horse blood $3 \mathrm{ml}$. After that, they were streaked onto modified Skirrow plates (Fernández et al. 1994) consisting of (w/v\%): Brucella agar (Difco) $4.3 \mathrm{~g}$; ferrous sulphate (Merck) $0.05 \mathrm{~g}$, sodium metabisulfite (Merck) $0.05 \mathrm{~g}$; sodium piruvate (Merck) $0.05 \mathrm{~g}$, vancomicin (Sigma) $1 \mathrm{mg}$; trimethoprim (Sigma)
$0.5 \mathrm{mg}$; polimixin B $250 \mathrm{IU}$; cephalotin (Sigma) 1 $\mathrm{mg}$; amphotericine (Squibb) $0.1 \mathrm{mg}$ and defibrinated horse blood $5 \mathrm{ml}$. The plates were incubated at $42^{\circ} \mathrm{C}$ for $48 \mathrm{~h}$ in an atmosphere of $5 \%$ $\mathrm{O}_{2}-10 \% \mathrm{CO}_{2}$ and $85 \% \mathrm{~N}_{2}$. Suspected colonies were identified to species level by their morphological characteristics, susceptibility to cephalothin and nalidixic acid, growth at 26,37 or $42^{\circ} \mathrm{C}$ and their biochemical profiles using the API Campy system (bioMérieux).

The growth capacity in different bloods containing media (sheep, pig and cow blood) was assessed by viable counts of each strain using the modified Miles and Misra method (Tresierra-Ayala et al., 1999). In brief, bacterial suspensions of each strain were prepared in distilled water $\left(3 \times 10^{8} \mathrm{CFU} / \mathrm{ml}\right)$; $\log _{10}$ serially diluted in $0.1 \%$ peptone water and $20 \mu \mathrm{l}$ from each dilution were seeded, in quintuplicate, onto blood agar plates. After $36 \mathrm{~h}$ of incubation at $42^{\circ} \mathrm{C}$ for $36 \mathrm{~h}$ under microaerophilic conditions, viable counts were determined.

The results were compared by the analysis of variance (ANOVA), provided by SPSS program.

\section{RESULTS AND DISCUSSION}

All the thermotolerant Campylobacter strains under study showed growth capacity in culture media supplemented with cow blood and pig blood, as well as in the media supplemented with sheep blood used as control. However, the analysis of the results showed that the growth on the culture medium with pig blood was higher than the growth observed on the culture medium supplemented with cow blood, being this difference statistically significant $(p \leq 0.05)$. On the other hand, the growth on the culture medium supplemented with pig blood was similar to that obtained on the culture medium supplemented with sheep blood ( $p>0.05)$. This trend was similar, regardless of the bacterial species studied and the animal source of the strains (Tables 1 and 2).

Therefore, it could be concluded that Campylobacter strains showed better growth in the presence of pig or sheep blood than with cow blood. Thus, of pig blood could be used as a supplement for culturing Campylobacter, especially when there was no availability of sheep or horse blood. This suggestion was in agreement with Anand et al. (2000), who expressed that in many developing countries, pigs, goats, or both were more readily available than sheep or horses 
and constituted an alternative source of blood for bacteriological purposes. Bolton et al. (1984) and Corry et al. (2001) suggested that blood as a supplement of the bacterial growth media prevented the accumulation of toxic oxygen derivatives (peroxides and superoxides) and allowed the growth of the organisms because these substances acted as quenching or detoxifying agents.

Table 1 - Growth capacity of Campylobacter strains isolated from domestic mammals, according to blood type used in the culture medium.

\begin{tabular}{|c|c|c|c|c|}
\hline \multirow{2}{*}{ Strain } & \multirow{2}{*}{ Origin } & \multicolumn{3}{|c|}{$\mathrm{CFU} / \mathrm{ml}$} \\
\hline & & Sheep blood & Cow blood & Pig blood \\
\hline C. jejuni 1 & Cow & $3,0 \times 10^{8}$ & $4,3 \times 10^{6}$ & $2,5 \times 10^{8}$ \\
\hline C. jejuni 2 & Cow & $6,5 \times 10^{8}$ & $4,5 \times 10^{5}$ & $4,5 \times 10^{8}$ \\
\hline C. jejuni 3 & Cow & $4,0 \times 10^{7}$ & $4,5 \times 10^{5}$ & $4,0 \times 10^{7}$ \\
\hline C. jejuni 4 & Cow & $4,3 \times 10^{8}$ & $7,5 \times 10^{6}$ & $3,3 \times 10^{8}$ \\
\hline C. jejuni 5 & Pig & $1,8 \times 10^{8}$ & $8,5 \times 10^{6}$ & $4,2 \times 10^{8}$ \\
\hline C. jejuni 6 & Cow & $3,6 \times 10^{6}$ & $4,5 \times 10^{5}$ & $6,6 \times 10^{6}$ \\
\hline C. jejuni 7 & Cow & $4,5 \times 10^{8}$ & $4,5 \times 10^{5}$ & $3,3 \times 10^{8}$ \\
\hline C. jejuni 8 & Pig & $3,6 \times 10^{8}$ & $1,2 \times 10^{6}$ & $2,7 \times 10^{8}$ \\
\hline C. jejuni 9 & Cow & $8,5 \times 10^{8}$ & $1,6 \times 10^{6}$ & $5,9 \times 10^{8}$ \\
\hline C. jejuni 10 & Pig & $6,7 \times 10^{8}$ & $1,2 \times 10^{6}$ & $6,4 \times 10^{8}$ \\
\hline C. jejuni 11 & Pig & $2,8 \times 10^{8}$ & $4,5 \times 10^{5}$ & $1,6 \times 10^{8}$ \\
\hline C. jejuni 12 & Cow & $4,8 \times 10^{8}$ & $4,5 \times 10^{5}$ & $3,8 \times 10^{8}$ \\
\hline C. jejuni 13 & Pig & $6,7 \times 10^{8}$ & $4,5 \times 10^{5}$ & $5,7 \times 10^{8}$ \\
\hline C. jejuni 14 & Pig & $5,1 \times 10^{8}$ & $1,7 \times 10^{6}$ & $3,6 \times 10^{8}$ \\
\hline C. jejuni 15 & Cow & $4,5 \times 10^{8}$ & $1,2 \times 10^{6}$ & $4,0 \times 10^{8}$ \\
\hline C. jejuni 16 & Cow & $4,3 \times 10^{8}$ & $1,5 \times 10^{6}$ & $4,2 \times 10^{8}$ \\
\hline C. jejuni 17 & Cow & $1,2 \times 10^{8}$ & $3,5 \times 10^{6}$ & $2,4 \times 10^{8}$ \\
\hline C. jejuni 18 & Pig & $3,6 \times 10^{8}$ & $4,5 \times 10^{5}$ & $2,6 \times 10^{8}$ \\
\hline C. jejuni 19 & Cow & $4,5 \times 10^{8}$ & $5,0 \times 10^{6}$ & $3,3 \times 10^{8}$ \\
\hline C. jejuni 20 & Pig & $3,0 \times 10^{8}$ & $1,2 \times 10^{6}$ & $2,7 \times 10^{8}$ \\
\hline C. jejuni 21 & Pig & $6,5 \times 10^{8}$ & $1,6 \times 10^{6}$ & $5,7 \times 10^{8}$ \\
\hline C. coli 1 & Pig & $5,7 \times 10^{8}$ & $1,6 \times 10^{6}$ & $3,6 \times 10^{8}$ \\
\hline C. $\operatorname{coli} 2$ & Cow & $5,6 \times 10^{6}$ & $4,5 \times 10^{5}$ & $5,5 \times 10^{6}$ \\
\hline C. coli 3 & Pig & $5,8 \times 10^{8}$ & $4,5 \times 10^{5}$ & $3,4 \times 10^{8}$ \\
\hline C. coli 4 & Pig & $4,2 \times 10^{8}$ & $4,5 \times 10^{5}$ & $3,6 \times 10^{8}$ \\
\hline C. coli 5 & Cow & $1,7 \times 10^{8}$ & $2,3 \times 10^{7}$ & $4,2 \times 10^{8}$ \\
\hline C. coli 6 & Pig & $7,5 \times 10^{7}$ & $4,6 \times 10^{6}$ & $4,6 \times 10^{7}$ \\
\hline C. coli 7 & Cow & $4,3 \times 10^{8}$ & $4,5 \times 10^{5}$ & $5,7 \times 10^{8}$ \\
\hline C. $\operatorname{coli} 8$ & Pig & $6,7 \times 10^{8}$ & $4,5 \times 10^{5}$ & $5,9 \times 10^{8}$ \\
\hline C. coli 9 & Pig & $5,1 \times 10^{8}$ & $1,7 \times 10^{6}$ & $4,8 \times 10^{8}$ \\
\hline
\end{tabular}


Table 2 - Growth capacity of Campylobacter strains isolated from domestic birds, according to blood type used in the culture medium.

\begin{tabular}{|c|c|c|c|c|}
\hline \multirow{2}{*}{ Strain } & \multirow{2}{*}{ Origin } & \multicolumn{3}{|c|}{$\mathbf{N}^{\circ} \mathrm{CFU} / \mathrm{ml}$} \\
\hline & & Sheep blood & Cow blood & Pig blood \\
\hline C. jejuni 22 & Chicken & $3,6 \times 10^{8}$ & $2,1 \times 10^{6}$ & $2,6 \times 10^{8}$ \\
\hline C. jejuni 23 & Chicken & $1,4 \times 10^{8}$ & $5,3 \times 10^{5}$ & $4,7 \times 10^{8}$ \\
\hline C. jejuni 24 & Chicken & $2,0 \times 10^{7}$ & $5,2 \times 10^{5}$ & $4,6 \times 10^{7}$ \\
\hline C. jejuni 25 & Chicken & $2,3 \times 10^{8}$ & $7,1 \times 10^{6}$ & $3,2 \times 10^{8}$ \\
\hline C. jejuni 26 & Duck & $3,8 \times 10^{8}$ & $4,5 \times 10^{6}$ & $4,4 \times 10^{8}$ \\
\hline C. jejuni 27 & Chicken & $3,6 \times 10^{7}$ & $5,1 \times 10^{5}$ & $6,6 \times 10^{7}$ \\
\hline C. jejuni 28 & Chicken & $4,2 \times 10^{8}$ & $5,3 \times 10^{5}$ & $3,8 \times 10^{8}$ \\
\hline C. jejuni 29 & Duck & $3,4 \times 10^{8}$ & $1,1 \times 10^{6}$ & $2,7 \times 10^{8}$ \\
\hline C. jejuni 30 & Chicken & $3,5 \times 10^{8}$ & $1,3 \times 10^{6}$ & $4,9 \times 10^{8}$ \\
\hline C. jejuni 31 & Chicken & $2,7 \times 10^{8}$ & $1,2 \times 10^{6}$ & $6,4 \times 10^{8}$ \\
\hline C. jejuni 32 & Chicken & $2,8 \times 10^{8}$ & $5,2 \times 10^{5}$ & $2,6 \times 10^{8}$ \\
\hline C. jejuni 33 & Chicken & $4,2 \times 10^{8}$ & $5,5 \times 10^{5}$ & $3,8 \times 10^{8}$ \\
\hline C. jejuni 34 & Duck & $2,3 \times 10^{8}$ & $1,2 \times 10^{6}$ & $4,7 \times 10^{8}$ \\
\hline C. jejuni 35 & Duck & $3,6 \times 10^{7}$ & $5,2 \times 10^{5}$ & $6,6 \times 10^{7}$ \\
\hline C. jejuni 36 & Duck & $3,4 \times 10^{8}$ & $5,3 \times 10^{5}$ & $3,8 \times 10^{8}$ \\
\hline C. jejuni 37 & Duck & $4,2 \times 10^{8}$ & $5,1 \times 10^{5}$ & $4,7 \times 10^{8}$ \\
\hline C. coli 10 & Chicken & $3,7 \times 10^{8}$ & $5,2 \times 10^{6}$ & $5,5 \times 10^{8}$ \\
\hline C. coli 11 & Chicken & $3,1 \times 10^{8}$ & $1,7 \times 10^{6}$ & $4,8 \times 10^{8}$ \\
\hline C. coli 12 & Duck & $1,7 \times 10^{8}$ & $5,2 \times 10^{5}$ & $3,6 \times 10^{8}$ \\
\hline C. coli 13 & Duck & $5,9 \times 10^{6}$ & $5,3 \times 10^{5}$ & $5,7 \times 10^{7}$ \\
\hline C. coli 14 & Chicken & $5,8 \times 10^{8}$ & $5,8 \times 10^{5}$ & $3,4 \times 10^{8}$ \\
\hline C. coli 15 & Chicken & $4,2 \times 10^{8}$ & $6,0 \times 10^{6}$ & $3,8 \times 10^{8}$ \\
\hline C. coli 16 & Duck & $1,7 \times 10^{8}$ & $2,3 \times 10^{7}$ & $3,2 \times 10^{8}$ \\
\hline C. coli 17 & Chicken & $7,8 \times 10^{7}$ & $5,6 \times 10^{5}$ & $4,6 \times 10^{7}$ \\
\hline C. coli 18 & Duck & $3,4 \times 10^{8}$ & $1,3 \times 10^{6}$ & $2,6 \times 10^{8}$ \\
\hline C. coli 19 & Duck & $3,8 \times 10^{8}$ & $1,3 \times 10^{6}$ & $4,9 \times 10^{8}$ \\
\hline C. coli 20 & Duck & $3,1 \times 10^{8}$ & $6,7 \times 10^{6}$ & $4,8 \times 10^{8}$ \\
\hline C. coli 21 & Duck & $3,4 \times 10^{8}$ & $1,7 \times 10^{6}$ & $2,6 \times 10^{8}$ \\
\hline C. coli 22 & Duck & $3,8 \times 10^{8}$ & $1,2 \times 10^{6}$ & $3,8 \times 10^{8}$ \\
\hline C. coli 23 & Duck & $3,6 \times 10^{8}$ & $1,1 \times 10^{6}$ & $3,4 \times 10^{8}$ \\
\hline
\end{tabular}

Erythrocytes possess superoxide dismutase and catalase enzymes (Chauhan et al., 1982), some with more enzymatic activity than others, so this could influence on the detoxifying capacity of blood. Ruminant erythrocytes are remarkable for their choline-phospholipid anomalies (FlorinChristensen et al., 2001) that could have influence on their physiological activities. On the other hand, copper deficiencies in bovines give rise to an alteration in the antioxidant capacity (Sukalsky et al., 1997). Probably, due to those facts, the erythrocytes of cow blood could have a lower enzymatic activity than the sheep or pig erythrocytes.

From the resukts, it could be concluded that pig blood could be a suitable alternative to sheep blood for use in Campylobacter media in regions where sheep and horse blood were not readily available.

\section{ACKNOWLEDGEMENTS}

This work was supported by the Grants DIDUACH S-2007-37 and DID-UACH SE-1-2009.

\section{RESUMO}

Na cidade de Iquitos (Região Amazônica do Peru), tanto o sangue de carneiro quanto o de eqüino, ambos recomendados como suplemento nos meios de cultura para Campylobacter, são difíceis de encontrar. No entanto, sangues de bovino e de suíno são de fácil disponibilidade. Por esta razão, 60 amostras de Campylobacter termotolerantes (37 C. jejuni e 23 C. coli) isoladas de bovinos, suínos, frangos e patos (15 amostras de cada animal) foram utilizadas para estabelecer sua capacidade 
de crescimento em meios de cultura contendo sangue de bovino ou de suíno como potenciais substitutos do sangue de carneiro ou de eqüino. A capacidade de crescimento foi estabelecida através da contagem de células viáveis utilizando o método de Miles e Misra modificado. Todas as amostras de Campylobacter mostraram melhor crescimento em meios suplementados com sangue de eqüino ou de suíno. Estes resultados permitem propor o uso de sangue de suíno como suplementos em meios de cultura para Campylobacter.

\section{REFERENCES}

Anand, C.; Rhonda, G.; Helene, S.; Fonseca, K. and Olsen, M. (2000), Pig and goat blood as substitutes for sheep blood in blood-supplemented agar media. $J$ Clin Microbiol, 38, 591-594.

Bolton, F. J.; Hutchinson, D. N. and Coates, D. (1984), Blood-free selective medium for isolation of Campylobacter jejuni from feces. J Clin Microbiol, 19, 169-171.

Chauhan, D.P.; Gupta, P.H.; Nampoothiri, M.R.; Singhal, P.C.; Chugh, K.S. and Nair, C.R. (1982), Determination of erythrocyte superoxide dismutase, catalase, glucose-6-phosphate dehydrogenase, reduced glutathione and malonyldialdehyde in uremia. Clin Chim Acta, 123, 153-159.

Corry, J.E.L.; Mansfield, L.P.; Forsythe, S.J. and Atabay, H.I. (2001), Culture media for the isolation of campylobacters, arcobacters and helicobacters. InCulture Media for Food Microbiology 2d. edition. ed. J.E.L. Corry, G.D.W. Curtis and R.M. Baird. Elsevier, Amsterdam, pp. 271-316.

Debruyne, L.; Gevers, D. and Vandamme, P. (2008), Taxonomy of the Family Campylobacteraceae. InCampylobacter Third Edition. ed. I. Nachamkin, C.M. Szymansky and M.J. Blaser. ASM Press, Washington DC, pp. 3-26.

Engberg, J. (2006), Contributions to the epidemiology of Campylobacter infections. Dan Med Bull, 53, 361-389.

Fernández, H. (1992), Increase of Campylobacter isolation rates using an enrichment medium. Rev Microbiol (S. Paulo), 23, 5-7.

Fernández, H (1992), Evaluation of a blood selective medium for the isolation of thermotolerant Campylobacter species. Arq Biol Tecnol, 35, 192195.

Fernández, H.; Kahler, K.; Salazar, R. and Rios, M. (1994), Prevalence of thermotolerant species of Campylobacter and their biotypes in children and domestic birds in Southern Chile. Rev Inst Med Trop, 36, 433-436.

Fernández, H. and Pisón, V. (1996), Isolation of thermotolerant species of Campylobacter from commercial chicken livers. Int J Food Microbiol, 29, 75-80.

Fernández, H.; Vera, F.; Villanueva, M. P. and García, A. (2008), Occurrence of Campylobacter species in healthy well-nourished and malnourished children. Braz J Microbiol, 39, 1-3.

Florin-Christensen, J.; Suarez C.E.; Florin-Christensen, M.; Wainszelbaum, M.; Brown, W.C.; McElwain, T.F. and Palmer, G.H. (2001), A unique phospholipid organization in bovine erythrocyte membranes. Proc Natl Acad Sci USA, 98, 7736-7741.

George, H.A.; Hoffman, P.S.; Smibert, R.M. and Krieg, NR. (1978), Improved media for growth and aerotolerance of Campylobacter fetus. $J$ Clin Microbiol, 8, 36-41.

Grados, O.; Bravo, N.; Black, R. and Butzler, J. (1988), Paediatric Campylobacter diarrhoea from household exposure to live chickens in Lima, Peru. Bull WHO, 66, 369-374.

Hoffman, P.; Krieg, N. and Smibert, R. (1979), Studies of the microaerophilic nature of Campylobacter fetus subsp. jejuni. I. Physiological aspects of enhanced aerotolerance. Can J Microbiol, 25, 1-7.

Stern, N.J. and Kazmi, S.U. (1989), Campylobacter jejuni. In- Foodborne Bacterial Pathogens. ed. M.P. Doyle. Marcell Dekker, Inc. New York, pp 71-110.

Sukalsky, K.A.; La Berge, T.P. and Johnson, W.T. (1997), In vivo oxidative modification of erythrocyte membrane proteins in copper deficiency. Free Radic Biol Med, 22, 835-842.

Tresierra-Ayala, A.; Bendayán, M.; Bernuy, A.; Espinoza, F. and Fernández, H. (1995), Carriage of the classical thermotolerant campylobacters in healthy domestic animals from Eastern Peru. Rev Inst Med Trop, São Paulo, 37, 537-539.

Tresierra-Ayala, A.; Ruiz, R.; Bendayán, M. and Fernández, H. (1999), Survival times of Campylobacter coli in sterilized buffalo milk. $J$ Vet Med, 46, 141-144.

Vera, H.D. and Power, D.A. (1980), Culture media. InManual of Clinical Microbiology, $3^{\text {rd }}$ edition. ed. E.H. Lennette, A. Ballows, W.J. Housler and H.J. Shadomy. American Society for Microbiology, Washington DC, pp. 965-999.

Received: March 17, 2009 Revised: October 26, 2009; Accepted: April 13, 2010. 